\title{
The Development of Sustainable Community Food Barn in Wonogiri Regency, Central Java, Indonesia
}

\author{
Erlyna Wida Riptanti', Suprapti, Aulia Qonita \\ Agribusiness Department, Faculty of Agriculture, Universitas Sebelas Maret \\ Jawa Tengah, Indonesia \\ * Corresponding author's email: erlynawida [AT] staff.uns.ac.id
}

\begin{abstract}
Food storage in the form of barn is mostly ineffective in Wonogiri. Even though, it has very significant role as buffer stock in the drought season. Meanwhile, the government's program initiates the activating of food barn, by providing fund assistance for barn building, rice miller and restock rice grains in the barn. However, it has not made the barn well developed, due to its dependency on the program.

The aim of this study is to construct the development of sustainable community's food barn. This study was used an exploratory method. The location of this study was selected purposively in Wonogiri. The result of this study showed that inactive food barn was caused by its poor management. Meanwhile, the active food barn functioned for savings and loans of rice grains. It has high dependency to the government program. The barn development needs a support from physical and non-physical environment to reach its sustainability.
\end{abstract}

Keywords--- Food barn, buffer stock, grains, rice, ineffectiveness

\section{INTRODUCTION}

Community has traditionally built up a food stock system for village and house hold, with at least in the form of community barn [20]. A food storage program is essential to provide for ourselves and our family members in an emergency condition [6]. Food barn has known as one of the food stock institution in the villages, it helps community to overcome food insecurity in drought season and disaster. The existence of food barn has been decreased, it caused by government intervention to increase the involvement of Logistics Agency (Bulog) and cheap food policy [13]. However, inconsistent and project oriented counseling activities causes ineffective counseling activities [19].

Food barn system in Central Java which functions as food stock, particularly in the sub-urban areas, has been difficult to find, now. Food barn has only available in eight regencies from 35 regencies and cities in Central Java. Numbers of food barn and its condition in Central Java shown in table 1:

Table 1. Numbers of Food Barn on Central Java in 2013

\begin{tabular}{|c|c|c|c|c|c|}
\hline Regency & $\begin{array}{l}\text { Numbers of } \\
\text { government's } \\
\text { active food barn }\end{array}$ & $\begin{array}{l}\text { Numbers of } \\
\text { government's non- } \\
\text { active food barn }\end{array}$ & $\begin{array}{l}\text { Numbers of } \\
\text { community's } \\
\text { active food barn }\end{array}$ & $\begin{array}{l}\text { Numbers of } \\
\text { community's } \\
\text { non-active food } \\
\text { barn }\end{array}$ & $\begin{array}{l}\text { Total amount of } \\
\text { food barn }\end{array}$ \\
\hline Purworejo & 31 & 27 & 312 & 93 & 463 \\
\hline Boyolali & 55 & 0 & 0 & 0 & 55 \\
\hline Wonogiri & 48 & 234 & 50 & 19 & 351 \\
\hline Karanganyar & 1 & 0 & 0 & 0 & 1 \\
\hline Rembang & 26 & 240 & 0 & 0 & 266 \\
\hline Temanggung & 9 & 0 & 29 & 167 & 205 \\
\hline Batang & 1 & 61 & 19 & 0 & 81 \\
\hline Tegal & 7 & 0 & 0 & 0 & 7 \\
\hline Total & 178 & 562 & 410 & 279 & 1,429 \\
\hline
\end{tabular}

Data source: Directorate General of Community and Village Empowerment, 2013. 
The amounts of non-active food barn that is managed by Wonogiri's governance are higher than the active ones. This is alarming, because the existence of food barn is getting eliminated. The aim of this study is formulating a model of development sustainable community's food barn. A strong current of food systems research holds that local food systems are preferable to systems at larger scales. Many assume that eating local food is more ecologically sustainable and socially justice. We draw on current scale theory in political and economic geography to argue that local food systems are no more likely to be sustainable or just than systems at other scales [5].

\section{RESEARCH METHOD}

This study was an exploratory research which is purposed to get an overview or review about food barn condition in Wonogiri regency, Central Java. The result of exploratory research are in-depth and contextual qualitative data which is supported with quantitative data. The applied method was survey which means the study of information from several dimension on a study object. The approach method was a cross sectional study which means a study in one particular time without conducting a treatment against the object. So, it draws a picture of situation in certain time.

The location of this study was purposively selected in Wonogiri regency. The region has both of government and community food barn in active and/or non-active condition, which are mostly non-active. The Wonogiri Food Security Office data in 2015 shows that the amount of community food barn in active condition is 28 units, while the amount of non-active ones is not recorded. At least eight active food barns and four non-active food barns in nine districts were selected for purposively sampling which were consist of:

a. Active food barn

1. Food barn of Banyakprodo village, Tirtomoyo Sub-District

2. Food barn of Gambiranom village, Baturetno Sub-District

3. Food barn of Gambiranom, Kismantoro Sub-District

4. Food barn of Pijiharjo village, Manyaran Sub-District

5. Food barn of Purwosari village, Wonogiri Sub-District

6. Food barn of Sendang Rejo village, Baturetno Sub-District

7. Food barn of Tawangharjo village, Giriwoyo Sub-District

8. Food barn of Jatisari village, Jatisrono Sub-District

b. Non-active food barn

1. Food barn of Kismantoro village, Kismantoro Sub-District

2. Food barn of Pidekso village, Giriwoyo Sub-District

3. Food barn of Trukan village, Pracimantoro Sub-District

4. Food barn of Tubokarto village, Pracimantoro Sub-District

The key informant of this study is an organizer of active and non-active food barn which is not only managed by community but also by government. Each food barn was purposively selected 1 organizer as key informant. Furthermore, key informant was purposively selected who is well known about food barn condition, who comes from village's administration agency, food security agency, farmer who is located around the food barn. The key informant of this study also is low income household who is located around the food barn. Respondent was selected as purposive approximately 3 people from each location of food barn.

Obtained data were collected from survey, it consist of local food barn condition, internal and external factors which has influenced to the existence of local food barn, food source in local food barn, institution and management of local food barn, access and distribution of main food to low income household in local food barn. Furthermore, secondary data were collected which is related to the object of study and local government policy about food security/ food barn.

Primary and secondary data were analyzed through descriptive analytic and it were deeply investigated. The analysis results are used to arrange the development of sustainable community's food barn.

\section{RESULT AND DISCUSSION}

Local food system could contribute to the reaching of food security, suggesting that the official interpretation of food security can be challenged to be more inclusive and to accommodate social justice imperatives [10]. The study about food barn has been massively done by other researchers. They observe food barn capacity, food barn shape, food barn pest, and food barn management $[1,3,15,17]$. The novelty of this study was focus on the management of sustainable community's food barn. The success of the development of community food barn could be seen from the indicator outcomes from Ministry Regulation No. 8 in 2014 :

1. Output indicators: a). Social fund aid has delivered for procurement of food stock and empowerment of community institutional and b). Facilitation had been done to increase the capability of food barn management (capacity building).

2. Outcome indicator: a) The availability and development of sustainable community's food stock b). The increase of community's role and ability in food barn management 
3. Benefit indicator: The establishment of management institution of community food barn which is independent and sustainable

4. Impact Indicator: Community's needs are fulfilled all the time (Agriculture Ministry, 2014).

This Ministry Regulation increases the numbers of food barn among communities and increases its competitiveness with private sectors in agriculture warehousing, it makes this segment more competitive but it needs a lot of effort to be done [4]. To ensure the affordable of long term food availability, the local ecology system which is a food distribution system should be maintained for its efficiency [21]. In addition, the result of this study about non-active food barn showed that there isn't any indicator achieved for successful food barn development. This basically caused by low capacity building in food barn management and institution.

The active food barn is utilized for: 1) crop yield storage 2) storage when crop yield price were low 3) storage for preserved food especially when drought season 4) prevention site for disaster time [8]. Furthermore, some food barns has led to the commercialization such as buy and sell of rice grains, i.e "Kridho Boga" food barn in Gambiranom village, Baturetno Sub-District; and "Sido Mulyo" food barn in Jatisari village, Jatisrono Sub-District. However, the gained profit is used to fund social function of the barn for its sustainability [14]. Identification and analysis result from active food barn can be observed in Table 2 .

Table 2. Actual condition of active food barn in Wonogiri regency.

\begin{tabular}{|l|l|r|}
\hline No & \multicolumn{1}{|c|}{ Explanation } & Percentage $(\%)$ \\
\hline 1 & Getting government aid for rice grains restock & 100 \\
\hline 2 & Barn function: Running social function, savings and loan function & 100 \\
\hline 3 & Steady institution of food barn & 25 \\
\hline 4 & Steady capacity building for barn administrators & 25 \\
\hline 5 & Productive barn activities lead to the commercialization & 37.5 \\
\hline 6 & Active role of community barn members in supporting barn activities & 37.5 \\
\hline 7 & Active role of youth farmers and farmers group in supporting barn & 25 \\
\hline 8 & Independent and sustainable food barn & 12.5 \\
\hline
\end{tabular}

Data source: Primary data analysis, 2016

The food barn organizer is commonly appointed by village officials and only some are appointed through direct vote. Program of administrators' capacity building improvement is limited, so that food barn activities are limited also which leads to stagnancy.

Table 2 showed that active food barn receive government aid and run its social function (save and loan). On the other hand, institution, capacity building of its organizer, program which leads to commercialization are low. In the long term, if the government's program were stopped, the food barn will be stopped (inactive) too. Some influenced factors which is identified are the lowering of farmer's young generation roles, farmer's group program only focus on production and it isn't related to food barn, food barn organizer are incapable and food barn only run its social function.

Food barn originally were established by farmer's group. However, in the development, the role of farmer's group toward food barn activities is decreased as well as farmer's young generation unwilling to contribute in the institutional food barn. This phenomenon is caused by the existence of more profitable business activities outside the food barn while the food barn cannot afford theirs. The yields which supposedly sold to the food barn are mostly sold to the broker. This problem causes restock of grains coming from purchasing to the third party instead from the food barn community members. The decreased support from surrounding environment both of physical environment (agricultural land) and non-physical environment (youth farmers, farmer's group and food barn institutional) will threaten the food barn's independency and sustainability. So, the development of sustainable community's food barn is needed.

The role of youth farmers as a driving force for agriculture development is highly expected in farmer's group. As agents of change, they play a role for farmers in giving knowledge and information, capacity building, and innovation of technology, they also assist the farmers to adapt against market change [9]. Besides, youth farmers play a role in fixing environmental conditions, particularly in damaged rice field area due to usage of chemical fertilizer or pesticide. The implementation of new technology which possibly decreased the negative impact of farming activities in soil condition and application of crop rotation could be a solution from this problem [16]. New technology in the form of the usage of organics fertilizer or pesticide which comes from biodiversity needs to be developed for supporting environment sustainability.

Youth farmers, farmer's group and food barns are inseparable elements in the developing of sustainable food barn. Youth farmers as the agents of change also play a role in farmer's group institutional and food barn. The developed model from the inseparable elements can be seen at Picture 1 below. Farmer's group as provider of agricultural products. The products itself are sold and purchased in community food barn. As per the extant policy of food grains issues, the principle of First-In-First-Out (FIFO) should be strictly followed with respect to the annual crop as well as within annual 
crop in which the supply are accepted [4]. The food barn provides needs of production tools and loans to achieve sustainable system.

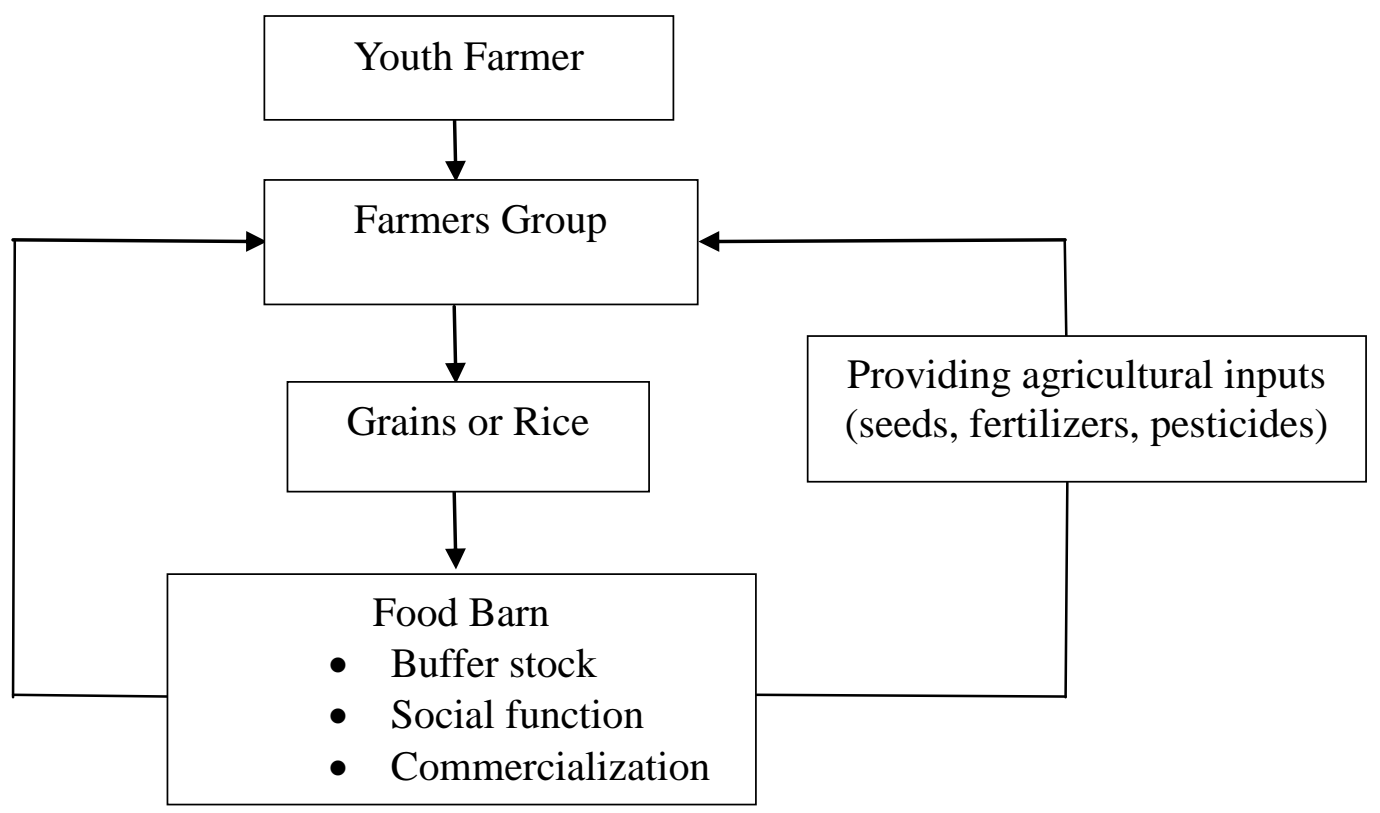

Picture 1. The development model of sustainable community's food barn

The development of sustainable food barn also depends on the role of woman's farmer group. The result of study [22] said that food security can be achieved by establishing community's food barn with empowerment of women's farmer group through proper counseling and establishment of working network. The administrator's capacity of farmer's group and barn should be built. Capacity building is applied through the enhancement of ability, skills, potential and talent, also mastering competencies so that a person, group or organization can be survived and able to appropriately overcome challenge and change [18]. The advanced capacity building will affect to the stronger institutional of barn and farmer's group.

Sustainable community's food barn has many functions i.e. buffer stock, social function and commercialization. The function should be balanced for its sustainability. Social function needs to manage in the basis of estimation and household estimation. It has managed the food percentage which is offered as a grant so it won't be a burdensome for food barn management. Social function of food barn overcomes emergency food problem such as food aid for people in disaster/ crop failure, death ceremony aid/ low income household.

As a buffer stock, it manages the price stabilization, the quantity and availability of food in the certain location. In the harvest season, food barn buy crop yield from farmer so the farmer's price isn't dropped. Meanwhile, in the drought season, food barn sell food stock to the community so the prices are relatively stable and food availability are well managed. The management of stock needs to be mastered by food barn organizer for a good cash flow.

Commercialization function was done to manage the cash stabilization of food barn. Food barn gets its profit from small business transaction of community's crop yield which is for social function fund and salary for food barn organizer. All this time, food barn organizer hasn't received their salary so it is reduced their motivation and responsibility in managing food barn. With salary, it would increase their motivation to manage food barn and leads to professionalism. Food barn can create a good cooperation between private, farmer's group and government as staple food.

Sustainable cooperation of farmer's group could be done through the providing of agricultural inputs (seeds, fertilizers, pesticides) which needs by farmer's group member. Food barn gives agricultural's credit inputs and the member of farmer's group sell their crop yield to the food barn as an exchange. This system helps farmer to avoid "ijon system" from broker (system that allows broker to buy farmer's crop yields before the harvest time with low cost). This problem caused by the emergency needs of household.

The community food barn is established with the ability of smallholder farmers, individually or in groups to effectively and efficiently store a significant part of their harvest at farm level. It is a major contributing factor for attaining food sufficiency and eliminate wide spread hunger in the region. It is able to run its function as buffer stock and its social function if it is supported with commercialization function. This function can be well run if the barn organizer has capacity to manage the food barn so that the independent and sustainable of community's food barn are achieved. 


\section{CONCLUSION}

Community's food barn has significant role as the community's buffer stock in the drought season. It supports food security in household and region level. The sustainability of food barn needs to be developed by activating three elements: youth farmers, farmer's group and the food barn itself. The youth role in farmer's group and barn is giving real influence in capacity building enhancement for its administrators and institution. This may lead to the sustainable of community's food barn.

\section{ACKNOWLEDGEMENTS}

Thanks to the Ministry of Research, Technology and Higher Education which has provide fund for this research with grant scheme "Leading Researches of Universities in 2016". Writers also thank to all parties who have supported by providing useful information to complete this article.

\section{REFERENCES}

[1] Abdul Awal, Afzal Hossain, Rostom Ali, Monjurul Alam. 2015. Effective Rice Storage Technologies for Smallholding Farmers of Bangladesh. The First International Congress on Postharvest Loss Prevention, Oct 4-7. Rome. Italy

[2] Albinus M. Makalle. 2012. Post Harvest Storage as a Rural Household Food Security Strategy in Tanzania. ARPN Journal of Science and Technology 2 (9) : 814-821.

[3] Angelita M. Pagcaliwagan, Melvin M. De Leon, Francis T. Del Rio, Rey Ryan M. Flores, Darwin Z. Hornilla. 2015. Warehousing Operation of National Food Authority in Batangas City, Philippines. International Journal of Academic Research in Economics and Management Sciences 4(2) : 1-10.

[4] Bhartendu Kr. Chaturvedi1, Lieutenant Colonel Anil Raj TA 2015. Agricultural Storage Infrastructure in India: An Overview. IOSR Journal of Business and Management (IOSR-JBM) 17(5) : 37-43.

[5] Branden Born \& Mark Purcell. 2006. Avoiding the Local Trap Scale and Food Systems in Planning Research. Journal of Planning Education and Research 26 : 195-207.

[6] Charlotte P. Brennand and Deloy G. Hendricks. 1995. Food Storage In The Home. Department of Nutrition \& Food Sciences. Utah State University

[7] Ditjen Pemberdayaan Masyarakat dan Desa. 2013. Data Pokok Ditjen PMD. Kementerian Dalam Negeri RI. Ditjen Pemberdayaan Masyarakat dan Desa. www.pdm.kemendagri.go.id

[8] Elly Rosana, Yulian Junaidi, and Feby Anjarosa. 2013. Diversity of South Sumatera Food Barn Meaning, Indonesia. International Conference on Business, Economics, and Social Sciences. 4-5 November. Bangkok. Thailand

[9] Frederick O. Wanyama. 2015. Cooperatives and the Sustainable Development Goals. International Labour Organization (ILO) and International Co-operative Alliance's (ICA).

[10] James Kirwan and Damian Maye. 2013. Food Security Framing Winthin UK and the Integration of Local Food System. Journal of Rural Studies 29 : 91-100.

[11] Kantor Ketahanan Pangan. 2015. Daftar Kelompok Lumbung Pangan Tahun 2014-2015. Kantor Ketahanan Pangan Kabupaten Wonogiri. Wonogiri

[12] Kementrian Pertanian. 2014. Peraturan Menteri Pertanian Republik Indonesia No 08/Permentan/OT.140/2014 Tentang Pedoman Pengembangan Lumbung Pangan Masyarakat Tahun 2014. Kementrian Pertanian Republik Indonesia. Jakarta

[13] Komala Sari. 2013. Analisis Pendapatan Petani Padi Dalam Kaitannya Dengan Keberadaan Lumbung Pangan Di Desa Pahang Asri Kecamatan Buay Pemuka Peliung Ogan Komering Ulu Timur. Jurnal Ilmiah AgrIBA No.2 Edisi September Tahun 2013

[14] Lestari Rahayu, Retno Wulandari, Retno Fajar Setyorini. 2015. The Food Barn Role in Sustainability of Food Security (A case study on Food Barn" Lestari Boga " in the Village Muntuk, Dlingo, Bantul Indonesia). International conference on Agro-industry (ICoA) 7-9 November. Matsuyama. Japan

[15] Luis A. Espino, Chris A. Greer, Randall G. Mutters and James F. Thompson. 2014. Survey of Rice Storage Facilities Identifies Research And Education Needs. California Agriculture 68 (1): 38-46.

[16] Madina A. Abdulkadyrova, Andzor H. Dikinov, Hassan È. Tajmashanova, Lomali A. Shidaeva and Eliza A. Shidaeva. 2016. Global Food Security Problems In The Modern World Economy. International Journal Of Environmental \& Science Education 2016 11(12) : 5320-5330.

[17] Martin Gummert and Chris Cabardo. 2013. Rice Storage. IRRI Training Module. International Rice Research Institute Los Banos. Philippines

[18] Morrison, Terrence. 2001. Actoinable Learning - A Handbook for Capacity Building Through Case Based Learning. ADB Institute

[19] Muchjidin Rachmat, Gelar Satya Budhi, Supriyati, dan Wahyuning K. Sejati. 2011. Existence and Role of Community Barn in Resolving Food Security Problems. Forum Penelitian Agro Ekonomi. 29(1) : 43 - 53.

[20] Rahman HPS, Purwoto A, Hardono GS. 2005. Kebijakan Pengelolaan Cadangan Pangan Pada Era Otonomi Daerah dan Perum Bulog. Forum Penelitian Agroekonomi 23 (2): 73-83. 
[21] Sabannavar and Harale. 2014. Food Security and Public Distribution System - A Macro Analysis. Indian Journal Of Applied Research 4 (8): 81 - 83.

[22] Yayuk Yuliatia and Riyanti Iskaskar. 2016. The Strategy to Increase Women Farmer's Participation in The Program of Village Food Barn in East Java. International Journal Of Environmental \& Science Education 11(12) : 57285735. 